\title{
AGGREGATE EARNINGS AND RETURNS IN BRAZIL
}

\author{
Talles Vianna Brugni 1 \\ Marcelo Cabus Klotzle 2 \\ Antonio Carlos Figueiredo Pinto 3 \\ Luiz Paulo Lopes Fávero ${ }^{4}$ \\ Muhhamad Safdar Sial 5
}

- Received: 12/20/2019 -. Approved: 05/29/2020 •.. Second Approved Version: 08/29/2020

\begin{abstract}
We used the method employed in Kothari, Lewellen and Warner (2006) to show the relationship between aggregate earnings and market returns in Brazil in the period from 1995 to 2017. Considering the findings found by Kothari, Lewellen and Warnet (2006), our results indicate that the theory of Bernard and Thomas (1990) is more consistent with the US market than with the Brazilian market, signaling that the aggregate post-earnings announcement drift tends to be larger in markets with higher earnings persistence, like Brazil. Our findings also indicate that the relationship between aggregate returns and earnings in Brazil tends to be positive for the current period and the next two quarters, corroborating the Sadka and Sadka (2009) study. Considering that the predictability of earnings in the US market is higher than that in Brazil, our results also support the argument by $\mathrm{He}$ and $\mathrm{Hu}$ (2014) that the relationship between aggregate earnings and returns is linked to each country's level of disclosure. However, new evidences reveal the influence of high interest rates on financial market results, suggesting that expectations of increased interest rates tend to reduce aggregate current returns in Brazil due to the possible migration of capital to lower risk, given the attractiveness of their returns in an environment of high inflation.
\end{abstract}

\footnotetext{
1 Associate Professor of Accounting and Finance at FUCAPE Business School. Av. Fernando Ferrari, 1358 - Boa Vista, Vitória - ES, Brazil. E-mail: tallesbrugni@fucape.br.

https://orcid.org/0000-0002-9025-9440
}

2 Associate Professor of Finance at PUC-RIO (IAG Business School). Rua Marquês de São Vicente, 225 - Gávea, Rio de Janeiro - RJ, Brazil. E-mail: klotzle@iag.puc-rio.br. https://orcid.org/0000-0002-5463-6333

3 Associate Professor of Finance at PUC-RIO (IAG Business School). Rua Marquês de São Vicente, 225 - Gávea, Rio de Janeiro - RJ, Brazil. E-mail: figueiredo@iag.puc-rio.br. https://orcid.org/0000-0002-1452-1240

4 Associate Professor of Applied Econometrics at University of São Paulo (FEA/USP). Av. Prof. Luciano Gualberto, 908 - Butantã, São Paulo - SP, Brazil. E-mail: Ipfavero@usp.br.

https://orcid.org/0000-0001-8516-6701

5 PhD (Accounting), Wuhan University. Assistant Professor at COMSATS University Islamabad (CUI). E-mail: safdar.sial786@gmail.com.

https://orcid.org/0000-0002-5473-8882

Revista Contabilidade Vista \& Revista, ISSN 0103-734X, Universidade Federal de Minas Gerais, 
Aggregate Earnings and Returns in Brazil

Keywords: Aggregate Earnings. Aggregate Returns. Risk. Interest Rates.

\section{LUCROS E RETORNOS AGREGADOS NO BRASIL}

\section{RESUMO}

O presente trabalho utilizou-se do método de Kothari, Lewellen e Warner (2006) para evidenciar a relação entre o anúncio dos lucros e o retorno de mercado no Brasil de forma agregada no período compreendido entre 1995 e 2017. Os resultados indicam maior aderência da teoria de Bernard e Thomas (1990) ao mercado americano do que ao mercado brasileiro, sinalizando que o PostEarnings Announcement Drift agregado tende a ser maior em mercados cuja persistência dos lucros é maior. Os achados também sinalizam que a relação agregada entre retornos e lucros no Brasil tende a ser positiva para o período corrente e para os dois trimestres seguintes, corroborando o estudo de Sadka e Sadka (2009). Considerando que a previsibilidade dos lucros no mercado americano é maior do que a do Brasil, os resultados suportam os argumentos de $\mathrm{He}$ e Hu (2014) de que a relação entre lucros e retornos agregados está ligada ao nível de disclosure de cada país. Por outro lado, novas evidências apontam para a influência das altas taxas de juros nos resultados do mercado financeiro, sugerindo que expectativas de aumento de juros tendem a reduzir os retornos agregados correntes no Brasil em função da possível migração de capital para investimentos de menor risco, haja vista a atratividade de suas rentabilidades em ambiente de alta inflação.

Palavras-Chave: Lucros Agregados. Retornos Agregados. Risco. Taxas de juros.

\section{INTRODUCTION}

The empirical relationship between earnings and returns on stocks has been widely discussed in academia since the 1960s. Benston (1967) was the first to investigate the relationship between changes in earnings and changes in stock prices, although the work of Ball and Brown (1968) is the most cited and considered seminal in this sense (Dechow, Sloan \& Zha, 2014). Since the studies by Ball and Brown (1968), it is known that earnings and stock price share a positive relationship. Even after four decades, this subject remains relevant (Brennan, 1991; Fama, 1998; Ball \& Sadka, 2015), especially because it is constantly revisited by new researchers.

For decades, the relationship between accounting earnings and stock prices have been evidenced in the accounting literature, considering variations in the scope of the firm, and seeking to explain, for example, specific properties of earnings and their relationship with the movement of prices (He \& Hu, 2014). To achieve this objective, studies have used cross-sectional research designs or considered the variations in individual characteristics of companies with panel data (Ball \& Sadka, 2015).

Ball and Sadka (2015) comment that researchers have traditionally assessed the influence of earnings and stock price characteristics, such as relevance, conservatism, analyst coverage, timeliness, volatility, trading volume, information 
asymmetry, and liquidity, considering the particularities of each company for formulating relationships or inferences between these characteristics. Such earnings properties, when analyzed at the firm level, do not easily map the wellbeing under the investor's perspective (Ball \& Sadka, 2015). A clear example of this is how the risk-return ratio perceived by the investor is associated with macroeconomic conditionsof a given market. For this reason, it is important to analyze the behavior of the aggregate earnings-returns relationship in the Brazilian financial market.

The first indications that such an aggregate reaction may be different about the price reaction to individual earnings disclosures were provided by Kothari, Lewellen and Warner (2006). For these authors, current aggregate returns were not related to past aggregate earnings in the US market, unlike what happens with the same relationship at an individual level, suggesting that stock prices neither underestimate nor overestimate the announcement of earnings when analyzed in an aggregate manner. Additionally, the authors found that aggregate current returns are negatively related to current prices, releasing new evidence that a fraction of shocks in aggregate returns can be explained by interest rate shocks.

Considering that Brazilian macroeconomic conditions are significantly different from the US market (Maia \& Menezes, 2014), we seek to answer the following research question: how does the market react to the announcement of earnings in Brazil when the focus is on the aggregate level? In this regard, we use fundamentals of Kothari, Lewellen and Warner (2006) to demonstrate whether their results are sustained in the Brazilian market.

The Brazilian macroeconomic environment is peculiar, especially when compared to developed countries, such as the environment analyzed by Kothari, Lewellen and Warner (2006). In Brazil, the magnitude of interest rates are significantly higher (Weisbrot, Johnston, Carrillo \& Mello, 2017) and, to the extent that interest rates significantly impact the volatility and return of the markets (Caselani \& Eid Jr, 2004; Kasman, Vardar \& Tunç, 2011), it is possible that the results found by Kothari, Lewellen and Warner (2006) are slightly different for Brazil. We base our expectation on the fact that aggregate earnings and returns tend to be more persistent and less volatile because they report more smoothly on individual accounting practices of companies, such as conservatism and earnings management (Ball \& Sadka, 2016).

Our findings suggest a positive relationship between aggregate earnings and returns, supporting the international evidence that this relationship tends to be positive in countries with lower levels of disclosure and persistence, as demonstrated by He and Hu (2014) and Sadka and Sadka (2009). On the other hand, this relationship tends to be less positive compared to the original results of Kothari, Lewellen and Warner (2006) for the US market, and negative when earnings-returns relationship was controlled by yield curve. There may be several hypotheses for this phenomenon. In addition to the higher volatility, Brazilian basic interest rate (a reference for remuneration for low-risk securities) has an amplitude that draws attention, suggesting that in environments with high interest rates, investors tend to migrate their investments to lower risk securities, considering the attractive rates of fixed income. Consequently, such capital flight in the variableincome market would reduce, in aggregate terms, the returns to shareholders, due to the sales force caused by this movement.

40 Revista Contabilidade Vista \& Revista, ISSN 0103-734X, Universidade Federal de Minas Gerais, Belo Horizonte, v. 32, n. 2, p. 38-58, maio/ago. 2021. 
Studies such as this have important implications for both academia and the market. From a strictly academic point of view, considering macroeconomic structures and their relationships with the properties of accounting earnings and their respective influences on the returns of the financial market represents a natural extension to this research. In other words, this consideration can be attributed to the interdisciplinary nature of research design and to the need to conduct studies that analyze phenomena that treat these relationships in an aggregate manner, which, to the best of our knowledge, were not conducted in a Brazilian context to date.

Our results provide new perspectives on the relationship between earnings and returns in Brazil. These findings are also expected to enable the development of new research in the area of finance and accounting, facilitating the discussion of price movements and its relationship with the Brazilian macroeconomic environment. From a practical point of view, assuming that developing countries with high interest rates have stocks with more volatile prices, and assuming that the aggregate earnings-return relationship in these environments have greater long-term persistence, this study clearly reinforces the importance of portfolio diversification for market agents, especially for investors with long-term bias.

\section{THEORETICAL PLATFORM}

\subsection{Review of the Literature on Aggregate Earnings and Returns}

Although most of the work on earnings and market returns in the accounting area has focused on an analysis of their relationship, considering the individual variations of the firms (Ball \& Sadka, 2015), it is possible to find studies in the literature that analyze variables such as earnings and returns in an aggregate manner. Ball and Brawn (1967), for example, provide evidence that firms' own earnings are a function of industrial production and aggregate earnings. Ball and Brown (1969) and Beaver, Kettler and Scholes (1970) analyzed the earnings betas from the perspective of the capital asset pricing model, considering the relationship between earnings and returns in a systemic manner.

This research field signals to an important anomaly found in financial markets: the "post-earnings announcement drift" phenomenon. Bernard and Thomas (1989) showed the competing understanding of this phenomenon and how it occurs in US Market. According to them (Bernard \& Thomas 1989; 1990), financial markets tend to present a delay in the complete understanding of the relationship between earnings and returns, later recognized by Fama (1998).A part of this phenomenon can be analyzed using the aggregate approach, in order to improve the understanding of the earnings-returns behavior in larger terms, and in a macroeconomic way.

In this regard, Kothari, Lewellen and Warner (2006) shed light on a new stream of research as they identify a phenomenon that is contrary to the findings already consolidated in academia in terms of the earning-return ratio within the firm. The authors found that aggregate growth of earnings is negatively related to aggregate stock returns, contradicting the expectations at the firm level, that earnings are positively related to the current stock returns.

Along these lines, Sadka and Sadka (2009), studying the phenomenon of predictability in the financial market and focusing on the relationship between 
earnings and returns, both at the aggregate and specific levels, offer a complementary explanation to the study by Kothari, Lewellen and Warner (2006). These authors found that the change in aggregate earnings is significantly more predictable than the change in earnings at the firm level, suggesting that aggregate earnings provide less new information to diversified investors, justifying the negative relationship between aggregate earnings and returns at the macro level.

In this sense, Ball, Sadka and Sadka (2009) found that aggregate earnings, although negatively correlated with current aggregate returns, are positively correlated with past aggregate returns, ratifying the findings of Kothari, Lewellen and Warner (2006). This is consistent with the literature establishing a relationship between earnings and returns within the firm, which shows that the market anticipates much of the variation in earnings (Beaver, Lambert \& Morse, 1980; Collins \& Kothari, 1989; Kothari \& Sloan, 1992; Collins, Kothari, Shanken \& Sloan, 1994; Ball, Sadka \& Sadka, 2009).

Chen, Jiang and Lee (2015) extend the time horizon of Kothari, Lewellen and Warner (2006) and find that although the behavior of the (current) aggregate earning/return ratio is consistent over time (significantly negative), there are periods when the relationship between aggregate earnings and aggregate returns is positive (especially before the 1960s and after Sarbanes Oxley). This finding corroborates the studies of Kothari, Lewellen and Warner (2006) and Sadka and Sadka (2009) and shows that the negative relationship is not sustained in some specific periods.

Gallo, Hann and Li (2016) present results that may explain the findings of Chen, Jiang and Lee (2015). This is evident from the former study's results that reveal associations between market behavior in the interpretation of the aggregate earning-return ratio and political and regulatory uncertainties. For the authors, the market reaction to political uncertainties drives the negative relationship between earnings and aggregate returns.

Unlike the American evidence, $\mathrm{He}$ and $\mathrm{Hu}$ (2014) present arguments that the phenomenon of the inverse relationship between the announcement of earnings and aggregate returns in the US financial market is different from that of the other markets. For the authors, most countries show a positive and significant relationship between aggregate earnings and aggregate current returns. According to their findings, a possible explanation for the phenomenon may be related to the quality (disclosure) of the financial information disclosed.

$\mathrm{He}$ and $\mathrm{Hu}$ (2014) highlight that the relationship between earnings and aggregate returns becomes less positive in countries that maintain greater transparency when disclosing financial information. In other words, countries wherein published financial information tends to help market analysts more accurately, the relationship between aggregate earnings and aggregate returns tends to be negative, reinforcing the findings of Sadka and Sadka (2009). In this regard, we present our first hypothesis:

$\mathrm{Hl}$ : Aggregate earnings-returns relationship is significantly positive in Brazil.

On the other hand, Zolotoy, Frederickson and Lyon (2017) argue that the direction of the relationship between earnings and aggregate returns depends on 
economic conditions and the structure of the financial market. According to the authors, depending on these characteristics, market participants may rely or doubt the informativeness of the aggregate earnings information on the expected variation in the economy's interest rate, the market risk premium, and future aggregated cash flow. An essential finding of that study is that market participants rely on the informativeness of the aggregate earnings information on changes in interest rate expectations (market risk premium) when the sign of the relationship between aggregate earnings and returns is negative (positive).

In this regard, we expect that the Brazilian interest rates can impact the longterm relationship between aggregate earnings-returns. Despite the Brazilian level of disclosure and transparency, besides the monitoring power of the markets agent is weaker (Lopes \& Alencar, 2010), Brazil has some peculiarities that make the study relevant, such as high interest rates (Arida, Bacha \& Lara-Resende, 2004), higher country risk, weak investor protection, and lower levels of transparency visà-vis the developed countries (Lopes \& Alencar, 2010). Such characteristics, as pointed out by the underlying theory, tend to modify the relationships between earnings and returns in the financial market. In this regard, we present our hypothesis:

$\mathrm{H}$ 2: Aggregate earnings-returns relationship is significantly negative in Brazil, when controlled by macroeconomic conditions.

Ball and Sadka (2015) is an important reference to demonstrate the relevance of this research design, supporting the idea that the metrics that analyze the earnings-returns relationship with a "firm-level" approach may not be relevant for investors with diversified portfolios. This, in turn, produces misleading effects with regards to the influence of accounting information on the return on investment for this type of investor. Since diversified investors are also important agents in Brazil, besides the fact there is no literature exploring this issue in the Brazilian market, understanding the relationship between earnings and returns in an aggregate manner in this country is relevant because it serves a significant portion of domestic financial market agents and it sheds light on a new approach to the earnings-price ratio in Brazil.

\section{METHOD}

The financial data are quarterly in nature. They were collected using Economática® software, and include all shares (disregarding other types of trading, such as ADRs and funds) of Brazilian companies during 1995 and 2017. Our sample is justified considering that before 1995 the interest rates of the economy showed abnormal variations in behavior. Furthermore, they do not include financial and insurance companies because of the difficulty in estimating the cash flow of financial services companies and the regulatory issue involving the insurance market. Furthermore, we do not differentiate between earnings and loss in our models. We consider that loss is normal for firms in some periods, especially when the analysis consider long-term associations. Then, we understand that our models is not expected to control this differences.

Considering that our data are aggregated quarterly, our tests are performed with regressions in time series, and our database totals 87 observations for each equation. The number of observations in our database is not a problem, 
considering the variability of the data and the number of coefficients used in our models (Hyndman \& Kostenko, 2007). Additionally, we apply winsorization in order to mitigate the effect of outliers on the coefficients.

The econometric model used follows Kothari, Lewellen and Warner (2006) and, in this sense, the model will regress the aggregate market return against current and past aggregate earnings, according to equation 01 , below:

$$
R_{t+k}=\alpha_{0}+\beta_{1} d E / S_{t}+e_{t+k}
$$

where: $R_{t+k}$ is the return for the quarter $t+k$, and $d E / s_{t}$ represents the earnings seasonally differentiated by the quarter $t$, scaled by the market value of the stock $(S=P)$ or by the book value of the stock $(S=B V)$. Returns range from $k=0$ to 4 future quarters.

In equation $01, k=0$ refers to the quarter in which earnings are measured, and $k=1$ refers to the quarter in which earnings are announced. This is because, according to the literature, the market absorbs much of the novelties in the period in which the earning is being ascertained $(k=0)$. However, the earnings, in the period in which are disclosed $(k=1)$, also provide new information to the market (Ball \& Brown, 1968; Foster, 1977; Kothari, Lewellen \& Warner, 2006).

The variation in the aggregate earnings is calculated in the following three ways: i) dE/BV_agg is equal to the sum of dE divided by the sum of BV for the firms in the sample; and ii) $\mathrm{dE} / \mathrm{MV} \_$ew and $\mathrm{dE} / \mathrm{MV} \_\mathrm{vw}$ are the averages, weighted equally and by the proportional market value, respectively.

Additionally, equation 01 was used with the approach of Fama and MacBeth (1973) to test the association between individual earnings and returns in Brazil to increase the robustness in the comparisons between the Brazilian and American markets.

While equation 01 aims to verify the impact of a specific quarter on the current quarter, equation 02 is used to verify the degree of relevance of each quarter and verify the occurrence of the "post-earnings announcement drift" phenomenon (Bernard \& Thomas, 1990; Barberis, Shleifer \& Vishny, 1998; Kothari, 2001).

$$
R_{t+k}=\alpha_{0}+\beta_{1} d E / S_{t-1}+\beta_{2} d E / S_{t-2}+\cdots+\beta_{5} d E / S_{t-5} e_{t} \text { (Eq. 02) }
$$

Additionally, the previous literature points to the fact that movements in interest rates complicate the understanding of the relationship between earnings and returns, at the macro level. As the behavior of interest rates in Brazil is different from that of the US market (Arida, Bacha \& Lara-Resende, 2004), it is expected that the results of this study will provide new evidence that will contribute to a better understanding of the earnings-return relationship in Brazil. Specifically, this evidence will diversify the understanding of the agents positioned in the market. Additionally, it will foment new research in the area of finance and accounting, facilitating discussion about the movement of prices and their relationship with the Brazilian macroeconomic environment.

Thus, it is appropriate to perform tests to identify the relationship between earnings and aggregate returns, assuming that these tend to be influenced by the 
interest rate. Along these lines, equation 01 was divided into two other equations (03 and 04) to measure this phenomenon, as follows:

$$
R_{t+k}=\alpha_{0}+\beta_{1} d E / S_{t}+\gamma_{1} \operatorname{res}\left(d E / S_{t}\right)+e_{t+k}
$$

where $d L$ representes the differentiated earnings in period $t, S$ representes the market value (P) or the book value (BV) of the stock, and res $\left(d E / s_{t}\right)$ was obtained from the residuals of Eq. 04, as follows:

$$
d E / S_{t}=\alpha_{0}+\beta_{1} \Delta S E L I C_{t}+\beta_{2} d E / S_{t-1}+e_{t}
$$

Note that we control the earnings-returns relationship, considering that $\beta_{1}$ adds an important macroeconomic effect in our tests, since Brazilian financial market presents a broader amplitude compared to US market (Maia \& Menezes, 2014; Weisbrot, Johnston, Carrillo \& Mello, 2017), besides that interest rates significantly impact the volatility and return of the markets (Caselani \& Eid Jr, 2004; Kasman, Vardar \& Tunç, 2011 ). Additionally, we consider important to mention that controlling the earnings-returns relationship by interest rate captures other important effects in financial markets, such as economic crisis and country risk (Vieira \& Holland, 2020).

\section{RESULTS AND DISCUSSIONS}

Table 1 presents the descriptive statistics for quarterly returns and earnings from 1995 to 2017. The weighted average quarterly return for the sample's market stocks over the entire period is $-0.64 \%$, while the weighted average quarterly return. Part of this negative return is explained by the period of the sample, since the weighted average quarterly market stock return for the period from 2002 to 2007, for example, is $0.89 \%$. Another crucial factor that explains this result comprises the companies sampled in this study.

Other data include the 10.38 standard deviation for the market stocks weighted return versus the standard deviation of 2.79 for the equally weighted return. This suggests that larger firms have a higher degree of risk than smaller firms in Brazil, as corroborated by the standard deviation of the stratified sample containing firms with market values in the first and third tiers. 
Table 1

Descriptive statistics of quarterly returns and earnings from 1995 to 2017.

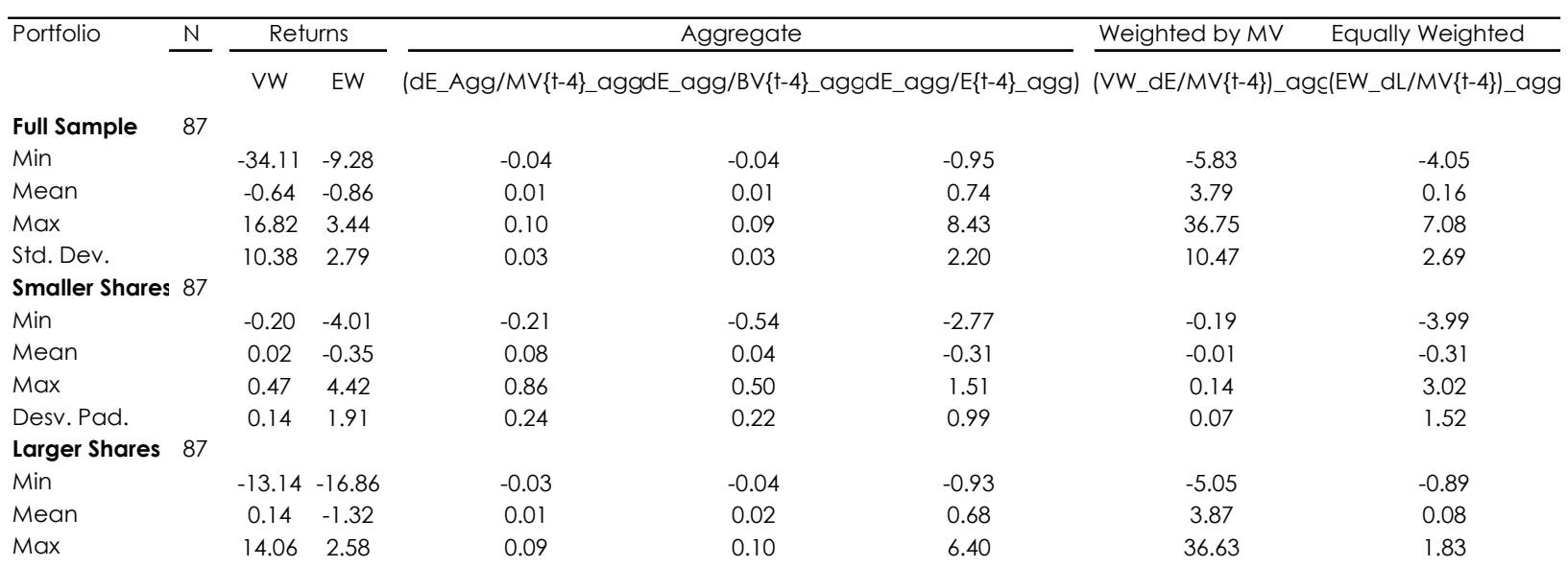

All variables are in percentages, except $\mathrm{N}$, which represents the number of companies in each portfolio. EW and $\mathrm{VW}$ are the weighted and market value-weighted returns, respectively. $\mathrm{dE}$ are the differentiated earnings, being equal to the current earnings minus the earnings of four previous quarters. $\mathrm{MV}$ is the market value of the stock and $\mathrm{BV}$ is the book value. Portfolio values are measured in the following three ways: (i) aggregate numbers, which are the sum of the numerator at the firm level divided by the sum of the denominator at the firm level, for all portfolio companies; (ii) weighted values also represent the average of the reasons at the firm level, using per share values; and (iii) market-weighted values represent the average of the ratios at firm level, weighted by market value, using per share values. The sample is winsorized at $2 \%$ (1\% on each tail) on a quarterly basis. Smaller Shares and Larger Shares are portfolios composed of shares with market value in the first and third tiers, respectively.

Source: Research data.

The aggregate tests focus on the variables dE_agg/MV, dE_agg/BV, and dE_agg/E because their results are representative and, as shown in Table 2 below, such aggregate series are highly correlated with each other and significant. It is important to mention that our time series are consistent with Box and Pierce (1970) and Ljung and Box (1978) adequacy tests. 
Table 2

Correlation between the measures of earnings and aggregate returns from 1995 to 2017. $\left(\mathrm{dE} \_a g g / \mathrm{E}\{\mathrm{t}-4\} \_a g g\right)\left(\mathrm{dE} \_a g g / \mathrm{BV}\{\mathrm{t}-4\} \_a g g\right)\left(\mathrm{dE} \_\mathrm{Agg} / \mathrm{MV}\{\mathrm{t}-4\} \_a g g\right)\left(\mathrm{EW} \_\mathrm{dE} / \mathrm{MV}\{\mathrm{t}-4\}\right) \_a g g\left(\mathrm{VW} \_\mathrm{dE} / \mathrm{MV}\{\mathrm{t}-4\}\right) \_a g g$

$\begin{array}{cc}\left.\text { (dE_agg/E }\{t-4\} \_a g g\right) & 1,0000 \\ \left.\text { (dE_agg/BV }\{t-4\} \_a g g\right) & 0,8333 \\ \left.\text { (dE_Agg/Mv }\{t-4\} \_a g g\right) & 0,8403 \\ \text { (EW_dL/Mv }\{t-4\}) \_a g g & 0,2146 \\ \text { (VW_dL/Mv }\{t-4\}) \_a g g & 0,2387\end{array}$

1,0000
0,9785
0,2010
0,2271

1,0000
0,1617

0,1617

1,0000

0,4582

1,0000

(E) stands for operating earnings. The change in earnings (dE) is scaled by the previous earnings, previous market value, and previous net worth. The change in earnings is calculated in the following three ways: aggregated values, identified by the "_agg", equal to the sum of the numerator divided by the sum of the denominator for all enterprises in the sample. Weighted values also represent the average of the ratios at firm level, using per-share values. Market-weighted values represent the average of the ratios at firm level, weighted by market value, using per-share values. The sample is winsorized at $2 \%$ (1\% on each tail) on a quarterly basis.

Source: Research data

Table 3 shows the autocorrelations for lags 1 to 5 and the estimated multiple regressions, including all the lags together.

$$
\begin{aligned}
& d L / S_{t}=\alpha_{0}+\beta_{k} d E / S_{t-k}+e_{t} \\
& d E / S_{t}=\alpha_{0}+\beta_{1} d E / S_{t-1}+\beta_{2} d E / S_{t-2}+\cdots+\beta_{5} d E / S_{t-5}+e_{t}
\end{aligned}
$$

Where $S$ is the company's market value (P) or shareholders' equity (BV). Panel A reports coefficients for individual firms, obtained through cross-sectional FamaMacBeth regressions. Panel B reports coefficients for the market portfolio, obtained through time series regressions.

Similar to Kothari, Lewellen and Warner (2006), Panel A reports positive autocorrelations for the first three lags-0.59, 0.30, and 0.03, respectively-and negative for lags 4 and $5--0.19$ and -0.11 , respectively - with the former three being significant $(p<.05)$. Comparatively, Kothari, Lewellen and Warner (2006) reported $0.34,0.18$, and 0.05 , respectively.

Additionally, the aggregate returns tend towards being more persistent than the returns of individual firms. Owing to the reasons above, the post-earnings announcement drift should be higher in the case of aggregate returns. It can be seen that Panel B presents results that are contrary to the theory of Bernard and Thomas (1990) and the findings of Kothari, Lewellen and Warner (2006). This can be attributed to the weaker phenomenon of post-earnings announcement drift and, possibly, to the lower persistence for aggregate returns in Brazil.

There may be the following two explanations for this phenomenon. The first explanation is attributed to the incipience of the Brazilian market in relation to the American market. In this scenario, it may be assumed that Brazilian investors tend to less efficiently understand the autocorrelation between quarterly earnings over time. This is because the coefficients found by Kothari, Lewellen and Warner (2006) for the US aggregate returns were higher than those for individual returns, signaling greater consistency of the theory of Bernard and Thomas (1990) with the US market than that with the Brazilian market. The second reason may be attributed to the influence of macroeconomic instabilities on the persistence of aggregate returns 
and, consequently, the reduced phenomenon of the post-earnings announcement drift in Brazil.

Table 3

Autocorrelation of differentiated quarterly earnings from 1995 to 2017.

\begin{tabular}{|c|c|c|c|c|c|c|c|}
\hline \multirow[t]{2}{*}{ Measure of Earnings } & \multirow[t]{2}{*}{ Lag } & \multicolumn{3}{|c|}{ Simple Regressions } & \multicolumn{3}{|c|}{ Multiple Regression } \\
\hline & & Coef. & t Stat. & adj. $R^{2}$ & Coef. & t Stat. & adj. $R^{2}$ \\
\hline \multicolumn{8}{|l|}{ PANEL A - Individual Firms } \\
\hline \multirow[t]{5}{*}{$\mathrm{dE} / \mathrm{MV}$} & 1 & 0,59 & 14,29 & 0,3359 & 0,61 & 15,03 & 0,4255 \\
\hline & 2 & 0,30 & 6,87 & 0,1328 & 0,03 & 3,19 & \\
\hline & 3 & 0,03 & 0,81 & 0,0563 & $-0,03$ & $-1,12$ & \\
\hline & 4 & $-0,19$ & $-9,70$ & 0,0591 & $-0,20$ & $-7,54$ & \\
\hline & 5 & $-0,11$ & $-4,99$ & 0,0335 & 0,14 & 5,5 & \\
\hline \multicolumn{8}{|l|}{ PANEL B - Aggregate } \\
\hline \multirow[t]{5}{*}{ dE/BV_agg } & 1 & 0,60 & 10,32 & 0,0334 & 0,74 & 8,48 & 0,0330 \\
\hline & 2 & 0,16 & 3,73 & 0,0413 & $-0,22$ & $-3,90$ & \\
\hline & 3 & $-0,12$ & $-1,12$ & 0,0417 & $-0,05$ & $-0,38$ & \\
\hline & 4 & 0,04 & $-3,10$ & 0,0413 & $-0,13$ & $-1,18$ & \\
\hline & 5 & $-0,10$ & $-1,12$ & 0,0423 & 0,12 & 1,39 & \\
\hline \multirow[t]{5}{*}{ dE/MV_ew } & 1 & 0,08 & 3,71 & $-0,0059$ & 0,07 & 3,64 & 0,0300 \\
\hline & 2 & 0,00 & 0,03 & $-0,0120$ & 0,01 & 0,12 & \\
\hline & 3 & $-0,06$ & $-0,51$ & $-0,0090$ & $-0,06$ & $-0,54$ & \\
\hline & 4 & 0,00 & $-0,01$ & $-0,0123$ & $-0,02$ & $-0,14$ & \\
\hline & 5 & 0,28 & 2,65 & 0,0692 & 0,29 & 2,60 & \\
\hline \multirow[t]{5}{*}{$\mathrm{dE} / \mathrm{MV}$ _Vw } & 1 & 0,29 & 2,74 & 0,0714 & 0,26 & 2,27 & 0,0416 \\
\hline & 2 & 0,14 & 3,29 & 0,008 & 0,09 & 3,78 & \\
\hline & 3 & $-0,03$ & $-0,26$ & $-0,0114$ & $-0,07$ & $-0,55$ & \\
\hline & 4 & $-0,10$ & $-0,91$ & $-0,002$ & $-0,08$ & $-0,64$ & \\
\hline & 5 & $-0,10$ & $-0,94$ & $-0,0014$ & $-0,04$ & $-0,39$ & \\
\hline
\end{tabular}

Panel A reports coefficients for individual firms, obtained through Fama-MacBeth crosssectional regressions. Panel B reports coefficients for the market portfolio, obtained through time series regressions. Earnings $(E)$ are the operating earnings of firms. Differentiated earnings (dE) are scaled both by the previous market value (MV) and by the previous BV value (BV). The change in aggregate earnings is calculated in the following three ways: i) dE / BV_agg is equal to the sum of dL divided by the sum of PL for the firms in the sample; and ii) $\mathrm{dE} / \mathrm{MV}$ _ew and $\mathrm{dE}$ / $M v_{-} v w$ are the weighted averages and the market value, respectively. The sample is winsorized at $2 \%$ ( $1 \%$ on each tail) on a quarterly basis. Bold represents significant coefficients at $5 \%$ significance or less.

Source: Research data.

The main tests explore how the market reacts to the uncertainty of added abnormal earnings in Brazil. In this sense, we verified the effect of the post-earning announcement drift for both individual firms and aggregated data. However, it has been found that the effect is less for aggregate data, unlike the findings of Kothari, Lewellen and Warner (2006) in the US market.

In Table 4, Panel A shows regression results for returns of the individual firms, while, in Panel B, it uses the aggregate approach. Panel A reports the FamaMacBeth regressions for individual firms. Confirming previous studies on the subject, it was found that the returns in the first three quarters are positively associated with 
current earnings, so that it is not possible to reject our hypothesis $(\mathrm{H} 1)$. However, unlike the US market, in Brazil, the coefficients are smaller, suggesting a more modest, though significant post-earnings announcement drift effect. The decline in coefficients with an increase in lags corroborates the theory of Bernard and Thomas (1990) that investors do not fully understand the phenomenon of persistent earnings.

\section{Table 4}

Aggregate quarterly returns and earnings from 1995 to 2017.

\section{Measure of \\ Earnings}

k Variation of Earnings

Coef. Stat. adj. $R^{2}$
Surprise in Earnings I Surprise in Earnings II $t$

Coef. Stat. adj. $R^{2}$

Coef. Stat. adj. $\mathbf{R}^{2}$

PANEL A -

Individual Firms

$\mathrm{dE} / \mathrm{MV}$

$\begin{array}{rrr}0 & \mathbf{0 , 0 8} & 3,69 \\ 1 & \mathbf{0 , 0 6} & 2,71 \\ 2 & \mathbf{0 , 0 3} & 2,28 \\ 3 & -0,01 & -0,98 \\ 4 & 0,00 & 0,09\end{array}$

-
-
-
-

$\begin{array}{ll}\mathbf{0 , 0 9} & 3,25 \\ \mathbf{0 , 0 4} & 1,98 \\ \mathbf{0 , 0 3} & 1,97 \\ 0,01 & 0,27 \\ 0,02 & 0,65\end{array}$

$\mathbf{0 , 1 2} 1,97$

$\mathbf{0 , 2 0} \quad 4,53$

$\mathbf{0 , 2 3} \quad 5,25$

$\mathbf{0 , 2 1} 3,90$

$\mathbf{0 , 1 3} 2,21$

PANEL B -

Aggregate dE/BV_agg

$\begin{array}{rrrr}0 & 16,40 & 2,41 & 0,0435 \\ 1 & 45,93 & 0,66 & 0,0034 \\ 2 & -82,72 & -1,16 & 0,0109\end{array}$

$\begin{array}{rrr}21,24 & 2,31 & 0,0469 \\ 14,66 & 2,34 & 0,0223 \\ -65,83 & -0,55 & 0,0045\end{array}$

$32,05 \quad 2,05$

0,0132

$\begin{array}{lll}\mathbf{5 3}, \mathbf{3 7} & 2,03 & 0,0367\end{array}$

$2-82,72-1,16$

$-65,83-0,55 \quad 0,0045$

$\mathbf{5 2 , 9 4} 2,18$

0,0358

\begin{tabular}{|c|c|c|c|c|c|c|c|c|c|c|}
\hline & 3 & $-68,47$ & $-0,82$ & 0,0075 & 4 & $-1,18$ & 0,0142 & 3 & 1,15 & 0,0106 \\
\hline & 4 & 0,12 & 0,14 & 0,0002 & $-37,88$ & $-0,41$ & 0,0015 & 43,18 & 0,14 & 0,0002 \\
\hline \multirow{5}{*}{ dE/MV_ew } & 0 & $-0,01$ & $-0,01$ & 0,0000 & 0,02 & 0,02 & 0,0000 & $-0,19$ & $-0,10$ & 0,0001 \\
\hline & 1 & $-0,30$ & $-0,36$ & 0,0016 & $-0,15$ & $-0,18$ & 0,0004 & 0,28 & 0,14 & 0,0002 \\
\hline & 2 & $-1,98$ & $-3,16$ & 0,0665 & $-2,00$ & $-3,22$ & 0,0675 & $-2,30$ & $-1,02$ & 0,0109 \\
\hline & 3 & 0,07 & 0,15 & 0,0001 & 0,05 & 0,10 & 0,0000 & $-2,44$ & $-1,16$ & 0,0122 \\
\hline & 4 & 0,31 & 0,30 & 0,0016 & 0,32 & 0,31 & 0,0018 & $-1,71$ & $-1,08$ & 0,006 \\
\hline \multirow[t]{5}{*}{$\mathrm{dE} / \mathrm{MV} \mathrm{V}_{\mathrm{V}} \mathrm{vW}$} & 0 & 0,19 & 0,99 & 0,0084 & 0,17 & 0,82 & 0,0062 & 0,98 & 0,81 & 0,0244 \\
\hline & 1 & 0,12 & 0,76 & 0,0032 & 0,23 & 1,57 & 0,0118 & 1,12 & 1,12 & 0,0325 \\
\hline & 2 & $-0,34$ & $-1,98$ & 0,0274 & $-0,40$ & $-2,49$ & 0,0349 & 0,32 & 0,60 & 0,0027 \\
\hline & 3 & $-0,10$ & $-0,68$ & 0,0020 & 0,18 & 1,14 & 0,0073 & 0,21 & 0,43 & 0,0011 \\
\hline & 4 & $-0,26$ & $-1,21$ & 0,0162 & $-0,26$ & $-1,01$ & 0,0150 & $-0,08$ & $-0,15$ & 0,0002 \\
\hline
\end{tabular}

The table reports the estimated coefficients, the $t$ statistic, and the adjusted $R^{2}$ when the quarterly stock returns is regressed on the differentiated quarterly earnings:

$R_{t+k}=\alpha+\beta d E / S_{t}+e_{t+k}$,

Where $\mathrm{dL}$ represents the differentiated quarterly earnings, and $\mathrm{S}$ represents both the market value (MV) and the book value (BV) of the firm. E represents quarterly operating earnings. $R_{t+k}$ ranges from $k=0$ to 4 future quarters $(k=0$ is the quarter in which earnings are measured; $k=$ 1 is the quarter in which earnings are typically announced). Panel A reports the estimated coefficients for individual firms, obtained by the Fama-MacBeth regression. Panel B reports the coefficients for market portfolios, obtained by time series regressions. $\mathrm{dE} / \mathrm{BV}$ _agg is the sum of $\mathrm{dE}$ divided by the sum of $\mathrm{BV}$ for all firms in the sample. $d E / M V \_e w$ and $d E / M V \_v W$ are the weighted ratios and the market value of each firm, respectively. The sample is winsorized at $2 \%$ ( $1 \%$ on each tail) on a quarterly basis. Bold represents significant coefficients at $5 \%$ significance or less. 
"Variation in Earnings" is the current value of $\mathrm{dE} / \mathrm{S}$, "Unexpected Earnings I" is the error term of the ARI model, and "Unexpected Earnings II" is the error term when $\mathrm{dE} / \mathrm{S}$ in $\dagger$ is regressed on $\mathrm{dE} / \mathrm{S}$ in $\mathrm{t}-1$ and on annual returns in $\mathrm{t}-1$.

Source: Research data.

Panel B shows the results for aggregate returns and, unlike the study by Kothari, Lewellen and Warner (2006) for the US market, the aggregate ratio of returns to earnings tends to be positive for the first two quarters. This corroborates the argument of Sadka and Sadka (2009) that the higher the predictability of aggregate earnings, the higher would be the negative relationship between earnings and aggregate returns. Considering that the predictability of earnings in the US market is higher than that in Brazil, the results support the argument of $\mathrm{He}$ and $\mathrm{Hu}(2014)$ that the relationship between earnings and aggregate returns is linked to each country's level of disclosure.

These results are also supported by Curtis, Kim and Oh (2020), considering that they indicate that positive associations in this sense may be related to the levels of persistence of earnings, in addition to relevant variations in interest rates.

\subsection{Aggregate Returns, Returns, and Brazilian Interest Rates}

The previous tests presented the following two results. First, aggregate earnings and returns are positively related in the Brazilian context, unlike the findings of Kothari, Lewellen and Warner (2006) for the United States of America. This result is consistent with the findings of $\mathrm{He}$ and $\mathrm{Hu}$ (2014) that the positive relationship trend is greater between earnings and aggregate returns when the country's level of disclosure is lower. It also confirms the findings of Sadka and Sadka (2009) by showing that the degree of predictability of earnings in Brazil tends to be smaller than that in the US market.

However, it is known that the interest rate behavior interferes with the relationship between earnings and returns (Shivakumar \& Urcan, 2017; Lett \& Ludvigson, 2004; Campbell \& Cochrane, 1999; Modigliani \& Cohn, 1979). Shivakumar and Urcan (2017) have recently demonstrated a reflection of the earnings growth of firms in the future interest rates of a given economy. For the authors, a portion of current earnings is transferred to the economy in the form of increased investments, contributing to the increase in interest rates and inflation.

Given this context, Table 5 presents tests on the aggregate earning/return ratio, considering the influence of the interest rate in this context. Our tests is consistent with $\mathrm{H} 2$ and show that aggregate earnings and returns in Brazil, when controlled by the interest rate term structure as a proxy for future interest expectations and risk, become negatively associated. This finding supports the original findings of Kothari, Lewellen and Warner (2006) for the American market and provides new evidence for the international literature to the extent that authors, such as He and Hu (2014) and Sadka and Sadka (2009), support the idea that positive relationships between earnings and aggregate returns in countries other than the United States of America can be explained by the lower level of disclosure and persistence of earnings. This shift of signal is also consistent with the findings of Zoloty et al. (2017). They posit that the sign of the relation can be 
different depending on the macroeconomic conditions.

These findings suggest that the absence of control over the discussed relationships by the countries' yield curve, as in the research of Sadka and Sadka (2009), may represent a relevant limitation when studying the relationship between earnings and returns at the macro level. Our findings add new perspectives on the influence of the economy's interest rate on the relationship between earnings and aggregate current and future returns. The use of such controls causes these findings to differ from those of $\mathrm{He}$ and $\mathrm{Hu}$ (2014), especially considering that their study is a cross-country level study.

The specific study for the Brazilian economy is relevant for understanding the relationship between earnings and aggregate returns in an environment of high interest rates. However, such study would become relevant if the tests performed by $\mathrm{He}$ and $\mathrm{Hu}$ (2014) on the influence of macroeconomics on this relationship aggregate several economies, whose current and future interest rate perspectives are different, as in the case of France and Germany (which have rates below $2 \%$ p.a. in different periods) and Brazil itself, whose historical minimum rate is $2.0 \%$ p.a. (after COVID-19), reaching more than $14.25 \%$ p.a, considering the last two decades.

Table 5

Aggregate quarterly returns and earnings from 2003 to 2017, controlled by the term structure of the interest rate

\begin{tabular}{|c|c|c|c|c|c|c|}
\hline \multirow[t]{2}{*}{ Meas ure of Profit } & \multirow[t]{2}{*}{ Lag } & \multicolumn{2}{|c|}{$\mathrm{dE} / \mathrm{S}$ (Beta) } & \multicolumn{2}{|c|}{$\mathrm{dE} / \mathrm{s}$ (Residuals) } & \multirow[t]{2}{*}{ adj. $R^{2}$} \\
\hline & & Coef. & t Stat. & Coef. & t Stat. & \\
\hline \multirow{5}{*}{ dE/BV_agg } & 0 & 109,48 & 0,58 & 373,19 & 2,56 & 0,0806 \\
\hline & 1 & $-186,59$ & $-0,93$ & 177,99 & 1,17 & 0,0048 \\
\hline & 2 & $-88,33$ & $-0,44$ & $-188,40$ & $-1,23$ & 0,0058 \\
\hline & 3 & 64,37 & 0,31 & $-114,35$ & $-0,72$ & 0,0268 \\
\hline & 4 & 182,49 & 0,88 & $-12,95$ & $-0,08$ & 0,0241 \\
\hline \multirow[t]{5}{*}{ dE/MV_ew } & 0 & $-6,08$ & $-2,61$ & 0,44 & 1,05 & 0,0816 \\
\hline & 1 & $-6,24$ & $-4,31$ & 0,07 & 0,15 & 0,0786 \\
\hline & 2 & $-1,68$ & $-0,93$ & $-1,05$ & $-2,09$ & 0,0518 \\
\hline & 3 & $-2,50$ & $-1,17$ & 0,18 & 0,61 & 0,0141 \\
\hline & 4 & 2,23 & 1,54 & 19,00 & 0,40 & 0,0118 \\
\hline \multirow[t]{5}{*}{ dE/VM_vw } & 0 & $-0,91$ & $-2,51$ & 0,09 & 3,00 & 0,0671 \\
\hline & 1 & $-1,05$ & $-5,20$ & 0,04 & 1,61 & 0,0723 \\
\hline & 2 & $-0,19$ & $-0,54$ & $-0,10$ & $-2,22$ & 0,0238 \\
\hline & 3 & $-0,53$ & $-1,29$ & $-0,04$ & 1,17 & 0,0222 \\
\hline & 4 & 0,50 & 1,42 & $-0,02$ & $-0,5$ & 0,0123 \\
\hline
\end{tabular}


The table reports the estimated coefficients, the $t$ statistic, and the adjusted $R^{2}$, when the quarterly stock returns is regressed against differentiated quarterly earnings, divided into the following two components:

$R_{t+k}=\alpha+\beta\left(d E / S_{t}\right)+\gamma \operatorname{res}\left(d E / S_{t}\right)+e_{t+k^{\prime}}$

where $\mathrm{dL}$ represents the differentiated quarterly earnings; $S$ represents the market value (MV) and the book value (BV) of the firm; and the two components of $\left(d E / S_{t}\right)$ are obtained from the following regression:

$\left(d E / S_{t}\right)=\alpha+\beta \Delta T E R M+\gamma d E / S_{t-1}+e_{t+k^{\prime}}$

where $\left(d E / s_{t}\right)$ is the calculated beta of the second regression, and res $\left(d E / S_{t}\right)$ is the residue of the second regression? The variable $\triangle T E R M$ represents the forward structure of the yield curve. $\mathrm{L}$ represents quarterly operating earnings. $R_{t+k}$ ranges from $\mathrm{k}=0$ to 4 future quarters $(\mathrm{k}=0$ is the quarter in which earnings are measured; $k=1$ is the quarter in which earnings are typically announced). dE/BV_agg is the sum of $\mathrm{dE}$ divided by the sum of $\mathrm{BV}$ for all firms in the sample. $\mathrm{dE} / \mathrm{MV}$ _ew and $\mathrm{dE} / \mathrm{MV}$ _ $\mathrm{vw}$ are the weighted ratios and the market value of each firm, respectively. The sample is winsorized at $2 \%$ (1\% on each tail). Bold represents significant coefficients at $5 \%$ significance or less.

Source: Research data.

Complementary tests of robustness, presented in Table 6, also suggest a possible migration of variable income investments to fixed income investments in countries whose expectation of future interest rates is higher, or maintained at higher levels, in relation to countries such as the US. This signals that the attractiveness of less risky investments in high interest rate environments negatively influences the relationship between earnings and returns.

\section{Table 6}

Robustness test for the relationship between returns and aggregate quarterly earnings, from 2003 to 2017 , controlled by the term structure of the interest rate.

\begin{tabular}{|c|c|c|c|c|c|c|}
\hline \multirow[t]{2}{*}{ Measure of Profit } & \multirow[t]{2}{*}{ Lag } & \multicolumn{2}{|c|}{$\mathrm{dES}$} & \multicolumn{2}{|c|}{ dTERM } & \multirow[t]{2}{*}{ adj. $R^{2}$} \\
\hline & & Coef. & t Stat. & Coef. & t Stat. & \\
\hline \multirow[t]{5}{*}{ dE/BV_agg } & 0 & 319,20 & 4,59 & $-1,51$ & $-3,96$ & 0,2040 \\
\hline & 1 & 105,84 & 1,26 & $-1,03$ & $-4,53$ & 0,0588 \\
\hline & 2 & $-98,60$ & $-0,97$ & $-0,28$ & $-0,74$ & 0,0191 \\
\hline & 3 & $-27,13$ & $-0,24$ & $-0,61$ & $-1,39$ & 0,0219 \\
\hline & 4 & 25,93 & 0,23 & 0,39 & 1,48 & 0,0241 \\
\hline \multirow[t]{5}{*}{ dEMV_ew } & 0 & 0,42 & 1,06 & $-1,29$ & $-3,09$ & 0,0819 \\
\hline & 1 & $-0,02$ & $-0,03$ & $-0,94$ & $-4,12$ & 0,0448 \\
\hline & 2 & $-1,04$ & $-2,12$ & $-0,18$ & $-0,50$ & 0,0517 \\
\hline & 3 & 0,20 & 0,72 & $-0,67$ & $-1,43$ & 0,0227 \\
\hline & 4 & 0,21 & 0,44 & 0,38 & 1,36 & 0,011 \\
\hline \multirow[t]{5}{*}{ dE/VM_vw } & 0 & 0,90 & 2,91 & $-1,29$ & $-3,04$ & 0,0908 \\
\hline & 1 & 0,03 & 1,10 & $-0,96$ & $-4,3$ & 0,0461 \\
\hline & 2 & $-0,96$ & $-2,33$ & $-0,28$ & $-0,81$ & 0,0257 \\
\hline & 3 & 0,05 & 1,13 & 0,67 & $-1,46$ & 0,0446 \\
\hline & 4 & $-0,03$ & $-0,47$ & 0,44 & 1,54 & 0,0123 \\
\hline
\end{tabular}


The table reports the estimated coefficients, the t statistic, and the $\mathrm{R}^{2}$ adjusted when the quarterly stock returns are regressed against differentiated quarterly earnings.

$R_{t+k}=\alpha+\beta d E / S_{t}+\beta \Delta T E R M+e_{t+k}$,

where $\mathrm{dE}$ represents the differentiated quarterly earnings, and $\mathrm{S}$ represents both the market value (MV) and the book value (BV) of the firm. E represents quarterly operating earnings. $R_{t+k}$ ranges from $k=0$ to 4 future quarters ( $k=0$ is the quarter in which earnings are measured; $k=$ 1 is the quarter in which earnings are typically announced). dE/BV_agg is the sum of dE divided by the sum of $B V$ for all firms in the sample. $d E / M V \_e w$ and $d E / M V \_\_w$ are the weighted ratios and the market value of each firm, respectively. The sample is winsorized at $2 \%$ ( $1 \%$ on each tail) on a quarterly basis. Bold represents significant coefficients at $5 \%$ significance or less.

Source: Research data.

Additionally, the signs indicate that a possible migration of capital from variable income investors to lower risk securities and attractive fixed remuneration also contributes to the reduction of the market value of publicly traded companies and, consequently, negatively influences the return to their shareholders.

\section{CONCLUDING REMARKS}

For decades, researchers in the accounting literature have been analyzing the relationship between earning and price, taking into account individual characteristics of firms. However, a part of the market tends to mitigate the risk of its investments through portfolio diversification (Ball \& Sadka, 2015). This highlights the importance of studying the relationship between earnings and returns on shares in the aggregate form.

Brazil has some peculiarities that make the study relevant, such as high interest rates, higher country risk, weak investor protection, and lower levels of transparency vis-à-vis the developed countries. Such characteristics, as pointed out by the underlying theory, tend to modify the relationships between earnings and returns in the financial market.

The results point toward a positive relationship between aggregate earnings and returns, supporting the international evidence that this relationship tends to be positive in countries with lower levels of disclosure and persistence, as demonstrated by He and Hu (2014) and Sadka and Sadka (2009).

However, considering the high current interest rates and future interest expectations in Brazil, this relationship tends to be negative, approaching the original results of Kothari, Lewellen and Warner (2006) for the US market.

There may be several hypotheses for this phenomenon. The Brazilian environment is relevant for studies of this nature, given that, in addition to being volatile, its basic interest rate (a reference for remuneration for low-risk securities) has an amplitude that draws attention. This interest rate ranged from $14.25 \%$ to $6.5 \%$ in the past 4 years, not to speak of the considerably higher rates over 10 years or more.

Considering that our results suggest that the relationship between earnings and returns in Brazil is positive when not controlled by interest rates and negative when controlled by interest rates, one of the hypotheses is that, in environments with high interest rates, investors tend to migrate their investments to lower risk 
securities, considering the attractive rates of fixed income. Consequently, such capital flight in the variable income market would reduce, in aggregate terms, the returns to shareholders, due to the sales force caused by this movement.

Another possibility lies in the fact that there may be a correlation between the term structure of the interest rate, levels of transparency, and persistence of earnings. This would ensure that the differences in results between countries in the relationship between earnings and aggregate returns are explained in a more robust manner. In this sense, a cross-country study evaluating this possibility is suggested for future research.

Our paper adds new perspectives on the influence of the economy's interest rate on the relationship between earnings and aggregate current and future returns. The use of such controls causes these findings to differ from those of $\mathrm{He}$ and $\mathrm{Hu}(2014)$, especially considering that their study is a cross-country level study. Additionally, assuming that developing countries with high interest rates have stocks with more volatile prices, and assuming that the aggregate earningsreturn relationship in these environments have greater long-term persistence, this study clearly reinforces the importance of portfolio diversification for market agents, especially for investors with long-term bias.

On the other hand, we state that our findings cannot be extrapolated, even for economies with high interest rates as Brazil. In this regard, we recommend more tests in this type of economy for future research in the sense provide external validity to our models.

\section{REFERENCES}

Arida, P., Bacha, E., \& Lara-Resende, A. (2004). High interest rates in Brazil: conjectures on the jurisdictional uncertainty. Rio de Janeiro: Casa das Garças. <http://www.econ.puc-rio.br/mgarcia/Macro\%20ll/ABRrevised.040303.PDF>

Ball, R., \& Brown, P. (1968). An empirical evaluation of accounting income numbers. Journal of Accounting Research, 159-178. <https://doi.org/10.2307/2490232>

Ball, R., \& Brown, P. (1969). Portfolio theory and accounting. Journal of Accounting Research, 300-323. <https://doi.org/10.2307/2489972>

Ball, R., Sadka, G., \& Sadka, R. (2009). Aggregate earnings and asset prices. Journal of Accounting Research, 47(5), 1097-1133. <https://doi.org/10.1111/j.1475679X.2009.00351.X>

Ball, R., \& Sadka, G. (2015). Aggregate earnings and why they matter. Journal of Accounting Literature, 34, 39-57. <https://doi.org/10.1016/j.acclit.2015.01.001>

Barberis, N., Shleifer, A., \& Vishny, R. (1998). A model of investor sentiment. Journal of financial economics, 49(3), 307-343. <https://doi.org/10.1016/S0304405X(98)00027-0> 
Beaver, W., Kettler, P., \& Scholes, M. (1970). The association between market determined and accounting determined risk measures. The Accounting Review, 45(4), 654-682.

Beaver, W., Lambert, R., \& Morse, D. (1980). The information content of security prices. Journal of Accounting and Economics, 2(1), 3-28. <https://doi.org/10.1016/0165-4101(80)90013-0>

Benston, G. J. (1967). Published corporate accounting data and stock prices. Journal of Accounting Research, 22-54. < https://doi.org/10.2307/2489907>

Bernard, V. L., \& Thomas, J. K. (1990). Evidence that stock prices do not fully reflect the implications of current earnings for future earnings. Journal of Accounting and Economics, 13(4), 305-340. <https://doi.org/10.1016/0165-4101 (90)90008$\mathrm{R}>$

Bernard, V. L., \& Thomas, J. K. (1989). Post-earnings-announcement drift: delayed price response or risk premium?. Journal of Accounting research, 27, 1-36. <https://doi.org/10.2307/2491062>

Brennan, M. J. (1991). A perspective on accounting and stock prices. The Accounting Review, 66(1), 67-79.

Box, G. and Pierce, D. (1970). Distribution of residual autocorrelation in autoregressive-integrated moving average time series models. Journal of American Statistical Association 65 (332), 1509-1526. <https://doi.org/10.1080/01621459.1970.10481180>

Caselani, C. N., \& Eid Jr, W. (2004). Volatilidade dos Retornos, Variações de Preços e Volumes Negociados: Evidências das Principais Ações Negociadas no Brasil. Sociedade Brasileira de Finanças.Campbell, J., \& Cochrane, J. (1999). By force of habit: a consumption-based explanation for aggregate stock market behavior. Journal of Political Economy, 107, 205-251. <https://doi.org/10.1086/250059>

Chen, Y., Jiang, X., \& Lee, B. S. (2015). Long-Term evidence on the effect of aggregate earnings on prices. Financial Management, 44(2), 323-351. <https://doi.org/10.1111/fima.12063>

Collins, D. W., \& Kothari, S. P. (1989). An analysis of intertemporal and crosssectional determinants of earnings response coefficients. Journal of accounting and economics, 11 (2-3), 143-181. <https://doi.org/10.1016/01654101 (89)90004-9>

Collins, D. W., Kothari, S. P., Shanken, J., \& Sloan, R. G. (1994). Lack of timeliness and noise as explanations for the low contemporaneuos return-earnings association. Journal of Accounting and Economics, 18(3), 289-324. <https://doi.org/10.1016/0165-4101(94)90024-8>

Curtis, A., Kim, C. J., \& Oh, H. I. (2020). Assessing the Structural Change in the 
Aggregate Earnings-Returns Relation. Available at SSRN. <https://doi.org/10.2139/ssrn.3517952>

Dechow, P. M., Sloan, R. G., \& Zha, J. (2014). Stock prices and earnings: A history of research. Annual Review of Financial Economics, 6(1), 343-363. 10.1146/annurev-financial-110613-034522. <https://doi.org/10.1146/annurevfinancial-1 10613-034522>

Fama, E. F. (1998). Market efficiency, long-term returns, and behavioral finance. Journal of financial economics, 49(3), 283-306. <https://doi.org/10.1016/S0304-405X(98)00026-9>

Fama, E. F., \& MacBeth, J. D. (1973). Risk, return, and equilibrium: Empirical tests. Journal of political economy, 81 (3), 607-636. <https://doi.org/10.1086/260061>

Foster, G. (1977). Quarterly accounting data: Time-series properties and predictiveability results. Accounting Review, 1-21.

Gallo, L. A., Hann, R. N., \& Li, C. (2016). Aggregate earnings surprises, monetary policy, and stock returns. Journal of Accounting and Economics, 62(1), 103120. <https://doi.org/10.1016/j.jacceco.2016.04.003>

He, W., \& Hu, M. R. (2014). Aggregate earnings and market returns: International evidence. Journal of Financial and Quantitative Analysis, 49(04), 879-901. <https://doi.org/10.1017/S0022109014000441>

Hyndman, R. J., \& Kostenko, A. V. (2007). Minimum sample size requirements for seasonal forecasting models. Foresight, 6(Spring), 12-15.

Kasman, S., Vardar, G., \& Tunç, G. (2011). The impact of interest rate and exchange rate volatility on banks' stock returns and volatility: Evidence from Turkey. Economic Modelling, 28(3), 1328-1334. <https://doi.org/10.1016/j.econmod.2011.01.015>

Kothari, C. R. (2004). Research methodology: Methods and techniques. New Age International.

Kothari, S. P., Lewellen, J., \& Warner, J. B. (2006). Stock returns, aggregate earnings surprises, and behavioral finance. Journal of Financial Economics, 79(3), 537568. <https://doi.org/10.1016/j.jfineco.2004.06.016>

Kothari, S. P. (2001). Capital markets research in accounting. Journal of accounting and economics, 31 (1), 105-231. <https://doi.org/10.1016/S0165-4101(01)00030$1>$

Kothari, S. P., \& Sloan, R. G. (1992). Information in prices about future earnings: Implications for earnings response coefficients. Journal of Accounting and Economics, 15(2-3), 143-171. <https://doi.org/10.1016/0165-4101(92)90016-U> 
Lettau, M., \& Ludvigson, S. (2004). Expected returns and expected dividend growth. Unpublished working paper, New York University, New York. <https://doi.org/10.3386/w9605>

Ljung, G. M., \& Box, G. E. (1978). On a measure of lack of fit in time series models. Biometrika, 65(2), 297-303. <https://doi.org/10.1093/biomet/65.2.297>

Lopes, A. B., \& de Alencar, R. C. (2010). Disclosure and cost of equity capital in emerging markets: the Brazilian case. The International Journal of Accounting, 45(4), 443-464. <https://doi.org/10.1016/j.intacc.2010.09.003>

Maia, A. G., \& Menezes, E. (2014). Economic growth, labor and productivity in Brazil and the United States: a comparative analysis. Brazilian Journal of Political Economy, 34(2), 212-229. <https://doi.org/10.1590/S0101-31572014000200003>

Sadka, G., \& Sadka, R. (2009). Predictability and the earnings-returns relation. Journal of Financial Economics, 94(1), 87-106. <https://doi.org/10.1016/j.jfineco.2008.10.005>

Shivakumar, L., \& Urcan, O. (2017). Why does aggregate earnings growth reflect information about future inflation?. The Accounting Review, 92(6), 247-276. <https://doi.org/10.2308/accr-51714>

Vieira, F., \& Holland, M. (2003). Country risk endogeneity, capital flows and capital controls in Brazil. Brazilian Journal of Political Economy, 23(1), 12-38. <https://doi.org/10.1590/0101-31572003-0703>

Weisbrot, M., Johnston, J., \& Carrillo, J. V. (2016). Brazil's enormous interest rate tax: can Brazilians afford it? (No. 2016-22). Center for Economic and Policy Research (CEPR).

Zolotoy, L., Frederickson, J. R., \& Lyon, J. D. (2017). Aggregate earnings and stock market returns: The good, the bad, and the state-dependent. Journal of Banking \& Finance, 77, 157-175. https://doi.org/10.1016/i.jbankfin.2017.01.005

This work was supported by the National Council for Scientific and Technological Development (CNPq - Brazil) [grant numbers: 150697/2017-1, 306532/2016-6 and 408470/2016-0]. 


\section{AUTHORS' CONTRIBUTIONS}

\begin{tabular}{|l|c|c|c|c|c|}
\hline \multicolumn{1}{|c|}{ Contributions } & $\begin{array}{c}\text { Talles } \\
\text { Vianna } \\
\text { Brugni }\end{array}$ & $\begin{array}{c}\text { Marcelo } \\
\text { Cabus } \\
\text { Klotzle }\end{array}$ & $\begin{array}{c}\text { Antonio } \\
\text { Carlos } \\
\text { Figueiredo } \\
\text { Pinto }\end{array}$ & $\begin{array}{c}\text { Luiz Paulo } \\
\text { Lopes } \\
\text { Fávero }\end{array}$ & $\begin{array}{c}\text { Muhhamad } \\
\text { Safdar Sial }\end{array}$ \\
\hline $\begin{array}{l}\text { 1. Idealization and conception } \\
\text { of the research subject and } \\
\text { theme }\end{array}$ & $\checkmark$ & $\checkmark$ & & & \\
\hline $\begin{array}{l}\text { 2. Definition of the research } \\
\text { problem }\end{array}$ & $\checkmark$ & $\checkmark$ & & & \\
\hline $\begin{array}{l}\text { 3. Development of Theoretical } \\
\text { Platform }\end{array}$ & $\checkmark$ & & $\checkmark$ & & \\
\hline $\begin{array}{l}\text { 4. Design of the research } \\
\text { methodological approach }\end{array}$ & $\checkmark$ & $\checkmark$ & & $\checkmark$ & \\
\hline 5. Data collection & $\checkmark$ & & & & $\checkmark$ \\
\hline $\begin{array}{l}\text { 6. Analyses and interpretations } \\
\text { of collected data }\end{array}$ & $\checkmark$ & $\checkmark$ & & $\checkmark$ & \\
\hline 7. Research conclusions & $\checkmark$ & & & & \\
\hline $\begin{array}{l}\text { 8. Critical review of the } \\
\text { manuscript }\end{array}$ & & & $\checkmark$ & $\checkmark$ & $\checkmark$ \\
\hline $\begin{array}{l}\text { 9. Final writing of the } \\
\text { manuscript, according to the } \\
\text { rules established by the Journal. }\end{array}$ & & & & & $\checkmark$ \\
\hline 10. Research supervision & & & $\checkmark$ & & \\
\hline
\end{tabular}

